\title{
POZIOM WIEDZY NA TEMAT SUPLEMENTACJI WITAMINY D WŚRÓD MŁODZIEŻY UCZĘSZCZAJĄCEJ DO SZKÓt ŚREDNICH WOJEWÓDZTWA PODKARPACKIEGO
}

\section{STUDY ON THE LEVEL OF KNOWLEDGE ABOUT VITAMIN D SUPPLEMENTATION AMONG YOUTH STUDYING IN SECONDARY SCHOOLS IN THE PODKARPACKIE VOIVODESHIP}

\author{
Katarzyna Kozubal ${ }^{a}$, Zbysław Mikowskib \\ Collegium Medicum, Uniwersytet Jana Kochanowskiego w Kielcach \\ ${ }^{\text {a }}$ https://orcid.org/0000-0003-0675-4199 \\ ${ }^{\mathrm{b}}$ https://orcid.org/0000-0002-3930-7179
}

DOI: https://doi.org/10.20883/pielpol.2021.6

\begin{abstract}
STRESZCZENIE
Wstęp. Ze względu na dużą rolę witaminy D w profilaktyce wielu schorzeń przeprowadzono badania dotyczące świadomej suplementacji tej witaminy wśród młodzieży.

Cel. Celem pracy było zbadanie wiedzy młodzieży szkół średnich na temat suplementów diety, w szczególności suplementacji witaminy D.

Materiał i metody. Do realizacji badania posłużono się metodą sondażu diagnostycznego, wykorzystując ankietę opracowaną przez autorów.

Wyniki. Większość badanych nie zna różnic między suplementami diety a lekami. Ankietowana młodzież cechuje się niską świadomością zaleceń dotyczących suplementacji witaminy D.

Wnioski. Istnieje potrzeba prowadzenia edukacji zdrowotnej wśród uczniów szkół średnich województwa podkarpackiego na temat suplementacji witaminy $D$, ze zwróceniem szczególnej uwagi na różnice występujące pomiędzy suplementami a lekami zawierającymi tę substancję.
\end{abstract}

SŁOWA KLUCZOWE: witamina D, suplement diety, młodzież.

\section{Wstęp}

W Polsce ze względu na szereg czynników, takich jak: szerokość geograficzna, niska podaż w diecie oraz profilaktyka nowotworów skóry (unikanie słońca, stosowanie kremów z filtrami UV), pogłębia się problem niedoboru kalcydiolu. W związku z tym istotnym dla zdrowia ludzi, a szczególnie młodych osób, jest skuteczne uzupełnianie niedoborów i właściwe suplementowanie witaminy D (cholekalcyferol).

$\mathrm{Na}$ rynku istnieje wiele preparatów z witaminą $\mathrm{D}$, z których większość można nabyć bez recepty. Ze względu na przepisy umożliwiające mniejszą kontrolę jakości suplementów diety niż leków, pojawia się nie-

\begin{abstract}
Introduction. Due to the large role of vitamin D in the prevention of many diseases, a study on the conscious supplementation of this vitamin among adolescents was conducted.

Aim. The aim of the study was to examine the knowledge of high school youth about dietary supplements, specifically vitamin D supplementation.

Material and methods. To carry out the task, the diagnostic survey method was applied, using a survey developed by the authors.

Results. Most interviewees do not know the differences between dietary supplements and medicines. The surveyed youth are characterized by low awareness of vitamin $D$ supplementation guidelines.

Conclusion. There is a need for health education among high school students of the Podkarpackie Voivodeship on vitamin D supplementation with special attention to the differences between supplements and drugs containing this substance.
\end{abstract}

KEYWORDS: vitamin D, dietary supplement, youth.

pewność, co do faktycznego składu takich wyrobów [1, 2]. Jednakże w ostatnim czasie nastąpił znaczny wzrost zainteresowania tego typu produktami z powodu szeroko zakrojonych działań reklamujących suplementy diety [3]. Warto więc zadać pytanie, czy młodzież szkół średnich wie, jakie są zalecenia suplementowania witaminy D oraz czy posiada odpowiednią wiedzę, aby wybrać właściwy dla siebie preparat?

$\mathrm{Na}$ podstawie ustawy z dnia 25 sierpnia $2006 \mathrm{r}$. o bezpieczeństwie żywności i żywienia oraz ustawy z dnia 6 września 2001 r. dotyczącej prawa farmaceutycznego można wywnioskować, jakie są różnice między suplementem diety a lekiem. Suplement jako 
środek spożywczy ma na celu uzupełnienie normalnej diety, odżywiania w witaminy, składniki mineralne lub inne substancje wykazujące efekt odżywczy. Z kolei produkt leczniczy jest substancją lub mieszaniną substancji, które mają zapobiegać lub leczyć choroby. Produkty lecznicze mogą być również podawane w celu postawienia diagnozy, posiadają wskazania, zatwierdzone przez Urząd Rejestracji Produktów Leczniczych, Wyrobów Medycznych i Produktów Biobójczych, natomiast suplementy diety nie posiadają żadnych zarejestrowanych wskazań. Leki podlegają ciągłemu nadzorowi i monitorowaniu jakości oraz bezpieczeństwa przez inspekcję farmaceutyczną, lekarzy, farmaceutów i podmiot wprowadzający do obrotu. Suplementy diety nie są kontrolowane pod względem bezpieczeństwa stosowania, jedynie podlegają kontroli jakości przeprowadzanej przez inspekcję sanitarną. Skutkuje to brakiem baz danych dotyczących działań niepożądanych stosowania suplementów diety. Na opakowaniu każdego produktu leczniczego znajduje się numer pozwolenia na dopuszczenie leku do obrotu, suplement diety nie posiada takiego numeru.

Od 2010 roku wpisano łącznie ponad 71 tysięcy produktów zakwalifikowanych jako suplement diety do rejestru produktów objętych powiadomieniem o pierwszym wprowadzeniu do obrotu na terenie Polski prowadzonego przez Główny Inspektorat Sanitarny [4].

Witamina D pełni ważną rolę w utrzymaniu homeostazy w organizmie człowieka. Charakteryzuje się działaniem plejotropowym. Odpowiada za utrzymanie odpowiedniego poziomu wapnia w surowicy krwi oraz jest niezbędna do prawidłowej mineralizacji tkanki kostnej. W swojej aktywnej postaci $1,25(\mathrm{OH})_{2} \mathrm{D}$ pobudza różnicowanie osteoblastów, dojrzewanie osteoklastów, reguluje ekspresję licznych genów w osteoblastach i osteoklastach. Witamina D hamuje resorpcję kostną, hamując sekrecję parathormonu. Wykazano, że suplementacja witaminą D i wapniem istotnie zmniejsza ilość złamań [5].

Badania wskazują na wpływ niedoboru witaminy D na rozwój cukrzycy i zwiększone ryzyko sercowo-naczyniowe [6]. Publikacje naukowe wskazują również na znaczący wpływ witaminy $D$ na odporność organizmu, na ekspresję genu kodującego peptyd LL-37, który należy do grupy katelicydyn - związków o działaniu przeciwwirusowym i bakteriobójczym [7]. Utrzymanie prawidłowego poziomu witaminy $D$ jest istotne również dla prawidłowego funkcjonowania żeńskiego układu rozrodczego, rozrodu i przebiegu ciąży, a jej niedobory mogą wiązać się z występowaniem endometriozy lub zespołu policystycznych jajników [8]. Co więcej witamina D wykazuje charakter neuroprotekcyjny. Udowodniono, że jej niedobory wiążą się ze zwiększonym prawdopodobieństwem zaburzeń nastroju, między innymi depresji, ze szczególnym uwzględnieniem osób z nadwagą i otyłych [9].

Dotychczasowe badania nie wykazały wpływu suplementacji witaminy D na zmniejszenie śmiertelności z powodów kardiowaskularnych wśród dorosłych, jednak zaobserwowano wpływ suplementacji witaminy D na zmniejszenie ryzyka śmierci związanej z chorobą nowotworową [10].

Z kolei przyjmowanie zbyt dużych ilości witaminy D może mieć negatywne konsekwencje. Przy stężeniu kalcydiolu większym niż $88 \mathrm{ng} / \mathrm{ml}$ pojawiają się hiperkalciuria i hiperkalcemia. Dodatkowo mogą wystąpić objawy splątania, poliuria, polidypsja, wymioty, osłabienie mięśni. Gdy stan ten występuje przewlekle, może doprowadzić do kamicy nerkowej, odwapnienia i bólu kości [11].

Ponadto szereg schorzeń może zwiększać ryzyko wystąpienia działań niepożądanych witaminy $\mathrm{D}$, nawet przy stosowaniu zalecanych dawek, są to: choroby z powstawaniem ziarniniaków np. sarkoidoza, gruźlica, pierwotna nadczynność przytarczyc, idiopatyczna hiperkalcemia niemowląt [11].

Celem kształcenia młodzieży w zakresie prawidłowych nawyków prozdrowotnych są prawidłowe zachowania w przyszłości, w dorosłym życiu. Ważne jest, aby młodzież rozumiała potencjalny wpływ suplementów diety na zdrowie. W związku z tym przeprowadzono kwerendę w zakresie prowadzonych badań, jednak nie natrafiono na żadne publikacje dotyczące tego zagadnienia.

\section{Cel pracy}

Celem badania było poznanie poziomu wiedzy młodzieży szkół średnich województwa podkarpackiego na temat różnic pomiędzy lekiem i suplementami diety, ze szczególnym uwzględnieniem świadomości na temat suplementacji witaminy D3. Zadaniem autorów było zebranie informacji, które:

- $\quad$ pozwoliłyby na określenie poziomu wiedzy młodzieży szkół średnich na przedstawione powyżej zagadnienie,

- umożliwiłyby ustalenie skali rozpowszechnienia stosowania zaleceń suplementacji witaminy D3.

\section{Materiał i metody}

Grupa badana

Badania przeprowadzono w 5 szkołach średnich w województwie podkarpackim. Ankietowana młodzież uczyła się w następujących miastach: w Kolbuszowej, Mielcu, Rymanowie Zdroju, Rzeszowie i Sanoku. Badania przeprowadzano od listopada do stycznia 2019 roku. Badaniami objęto 241 uczniów, z czego uzyskano 
201 prawidłowo wypełnionych kwestionariuszy ankiet, które zakwalifikowano do analizy komputerowej.

W badaniach zastosowano metodę sondażu diagnostycznego, wykorzystując kwestionariusz ankiety własnego autorstwa. Badani wypełniali kwestionariusze anonimowo. Badania przeprowadzono poprzez rozesłanie ankiet do losowo wybranych 5 szkół średnich województwa podkarpackiego z prośbą o wypełnienie przez uczniów i odesłanie ankiet do badaczy.

\section{Kwestionariusz ankiety}

Kwestionariusz badania ankietowego zawierał 12 pytań dotyczących obszaru zdrowego stylu życia, w tym suplementacji witaminy D3. Konstrukcja pytań w ankiecie miała charakter mieszany. Pierwsze cztery pytania dotyczyły danych społeczno-demograficznych tj. wiek, płeć, miejsce zamieszkania (wieś/miasto do 20 tys. mieszkańców/miasto od 20 tys. do 50 tys. mieszkańców/miasto powyżej 50 tys. mieszkańców) czy rodzaj szkoły (liceum ogólnokształcące/liceum sportowe /szkoła zawodowa/technikum). Kilka pytań było otwartych, które umożliwiały uczniom swobodne wypowiedzenie się w danym temacie. Treść pytań prezentowała się następująco:

5. Czy uważasz, że prowadzisz zdrowy tryb życia? Odpowiedzi zaznaczano w skali od 1 do 5 , gdzie 1 oznacza niezdrowy tryb życia, 5 oznacza zdrowy tryb życia.

6. Czy wiesz, czym różni się suplement diety od leku? Możliwe odpowiedzi to: a) tak - wiem, suplementy są produkowane z gorszych surowców niż leki; b) tak - wiem, suplementy niczym nie różnią się od leków, jeśli są sprzedawane w aptece; c) tak - wiem, suplementy są słabiej kontrolowane niż leki; d) nie jestem pewien/ pewna; e) nie wiem.

7. Czy znasz aktualne zalecenia dotyczące suplementacji witaminy D3? (odpowiedzi: tak/nie).

8. Ile IU witaminy D3 według aktualnych wytycznych dla Europy Środkowej powinna przyjmować osoba zdrowa w wieku 18-65 lat w okresie od września do maja? Możliwe odpowiedzi to: a) 500-1000 IU; b) 800-2000 IU; c) 1000-3000 IU; d) $5000 \mathrm{IU}$; e) nie wiem.

9. Czy uważasz, że potrzebujesz suplementacji witaminy D3? Możliwe odpowiedzi to: a) tak, przez cały rok; b) tak, okresowo; c) raczej nie; d) nie.

10. Czy stosujesz suplementację witaminy D3? (odpowiedzi: tak/nie).

11. Jeśli tak - jaką dawkę witaminy D3 dziennie przyjmujesz? Możliwe odpowiedzi to: a) $800 \mathrm{IU}$; b) $1000 \mathrm{IU}$; c) $2000 \mathrm{IU}$; d) $3000 \mathrm{IU}$; e) inną: ....

f) przyjmuję nieregularnie dawkę: ..

12. Czy stosujesz inne suplementy diety? Jeśli tak, podaj jakie: Możliwe odpowiedzi to: a) tak, są to: .... ; b) nie.

Analizę odpowiedzi i niezbędne obliczenia wykonano w programie Microsoft Excel.

\section{Wyniki}

Badana grupa uczniów składała się z 142 (70,6\%) kobiet i 59 (29,4\%) mężczyzn. Najwięcej badanych miało 18 lat, jednak średnia wieku wynosiła 17,53 lat (Tabela 1). Najwięcej osób uczestniczących w badaniu zamieszkiwało wieś, najmniej pochodziło z miasta o liczbie mieszkańców przekraczającej 50 tys.

Tabela 1. Podział badanych według płci i wieku Table 1. Respondents according to sex and age

\begin{tabular}{lcccccc}
\hline \multirow{2}{*}{ Płeć/Sex } & \multicolumn{5}{c}{ Wiek badanych w latach/ } & \multirow{2}{*}{$\begin{array}{c}\text { Razem/ } \\
\text { Total }\end{array}$} \\
\cline { 2 - 6 } & 15 & 16 & 17 & 18 & 19 & \\
\hline Kobiety/ & 1 & 22 & 33 & 66 & 20 & 142 \\
Females & $(0,49 \%)$ & $(10,95 \%)$ & $(16,42 \%)$ & $(32,84 \%)$ & $(9,95 \%)$ & $(70,65 \%)$ \\
Mężczyźni/ & 1 & 16 & 11 & 19 & 12 & 59 \\
Males & $(0,49 \%)$ & $(7,96 \%)$ & $(5,47 \%)$ & $(9,45 \%)$ & $(5,97 \%)$ & $(29,35 \%)$ \\
Razem/ & 2 & 38 & 44 & 85 & 32 & 201 \\
Total & $(1,00 \%)$ & $(18,91 \%)$ & $(21,89 \%)$ & $(42,29 \%)$ & $(15,92 \%)$ & $(100,00 \%)$ \\
\hline
\end{tabular}

Źródło: opracowanie własne.

Source: author's own analysis.

Spośród badanych 52 (25,9\%) osoby wiedziały, że suplementy diety są słabiej kontrolowane niż leki. Kolejne 24 (12,0\%) osoby sądziły, że suplementy są produkowane z gorszych surowców. Najmniej, 7 (3,5\%) badanych twierdziło, że suplementy niczym się nie różnią od leków, a 34 (16,9\%) osoby nie wiedziały, czym się różnią. Większość, 84 (41,8\%) badanych, nie była pewna różnic między lekiem a suplementem diety (Rycina 1).

Na pytanie o znajomość rekomendowanych dawek witaminy D zdecydowana większość, 138 (68,7\%) badanych, nie znało prawidłowej odpowiedzi. Nieodpowiednie dawki wskazało w sumie 41 (20,4\%) osób: mniejszą niż zalecaną 7 (3,5\%) osób, większą niż zalecaną 10003000 IU - 27 (13,4\%) osób i 5000 IU - 7 (3,5\%) osób. Jedynie grupa 22 (10,9\%) badanych wykazała znajomość rekomendowanego zakresu dawek (Rycina 2).

W odpowiedziach na pytanie o potrzebę suplementacji zdecydowanie zaprzeczyły $43(21,4 \%)$ osoby, a 53 $(26,4 \%)$ osoby raczej wykluczały taką potrzebę. Suplementację przez cały rok uznało za właściwą 36 (17,9\%) osób, natomiast okresową, najwięcej - 69 (34,3\%) osób (Rycina 3). 
Odpowiedzi badanych na pytanie 6./ Respondents' answers for the question 6 .

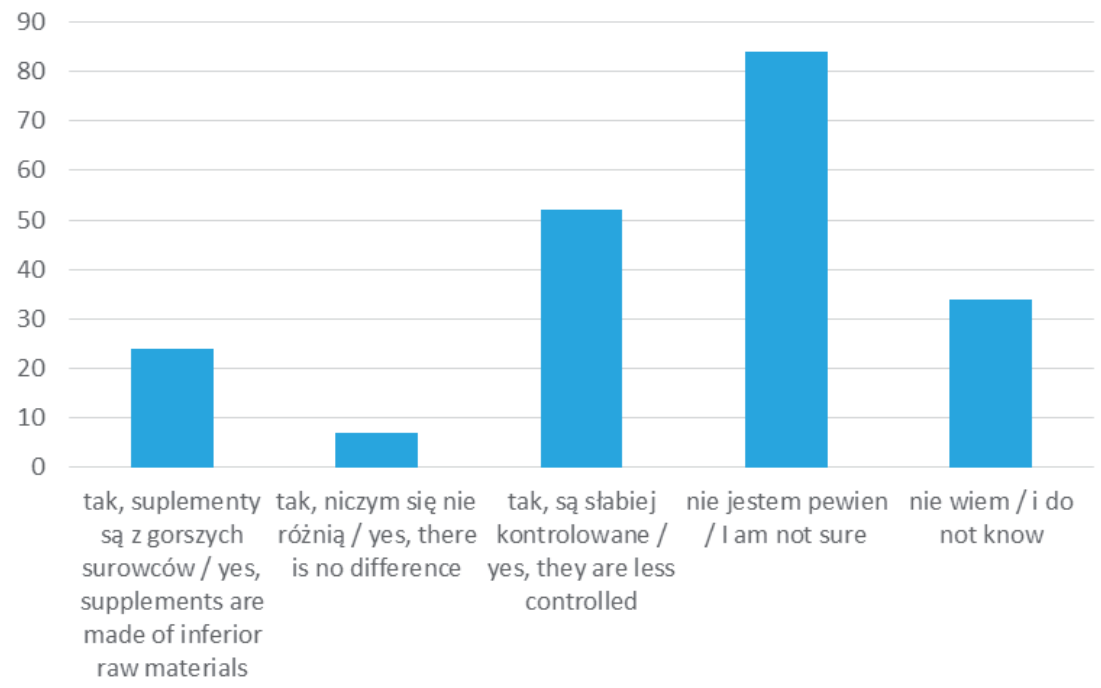

Rycina 1. Odpowiedzi badanych na pytanie „Czy wiesz, czym różni się suplement diety od leku?” Figure 1. Respondents' answers to the question, "Do you know how a dietary supplement differs from a drug?" Źródło: opracowanie własne.

Source: author's own analysis.

Odpowiedzi badanych na pytanie 8./ Respondents' asnwers for the question 8 .

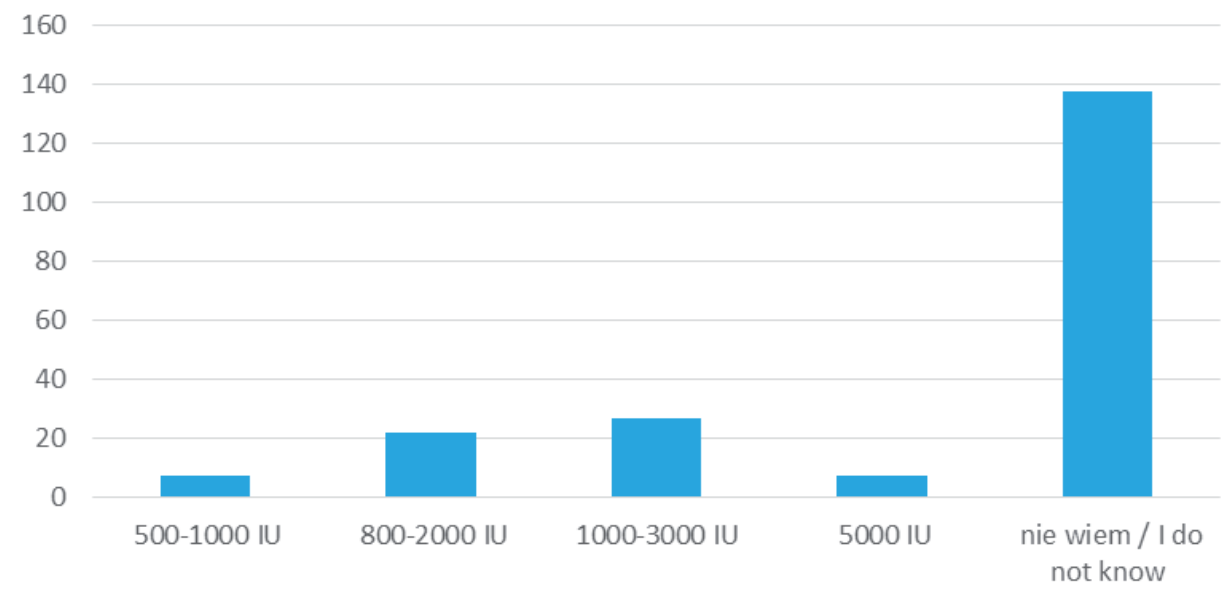

Rycina 2. Odpowiedzi badanych na pytanie „Ile IU witaminy D3 według aktualnych wytycznych dla Europy Środkowej powinna przyjmować osoba zdrowa w wieku 18-65 lat w okresie od września do maja?"

Figure 2. Respondents' answers to the question, "According to the current guidelines for Central Europe, how much IU of vitamin D3 should be taken by a healthy person ib age 18-65 in the period from September to May?"

Źródło: opracowanie własne.

Source: author's own analysis. 


\section{Odpowiedzi badanych na pytanie 9./ Respondetns' answers for the question 9 .}

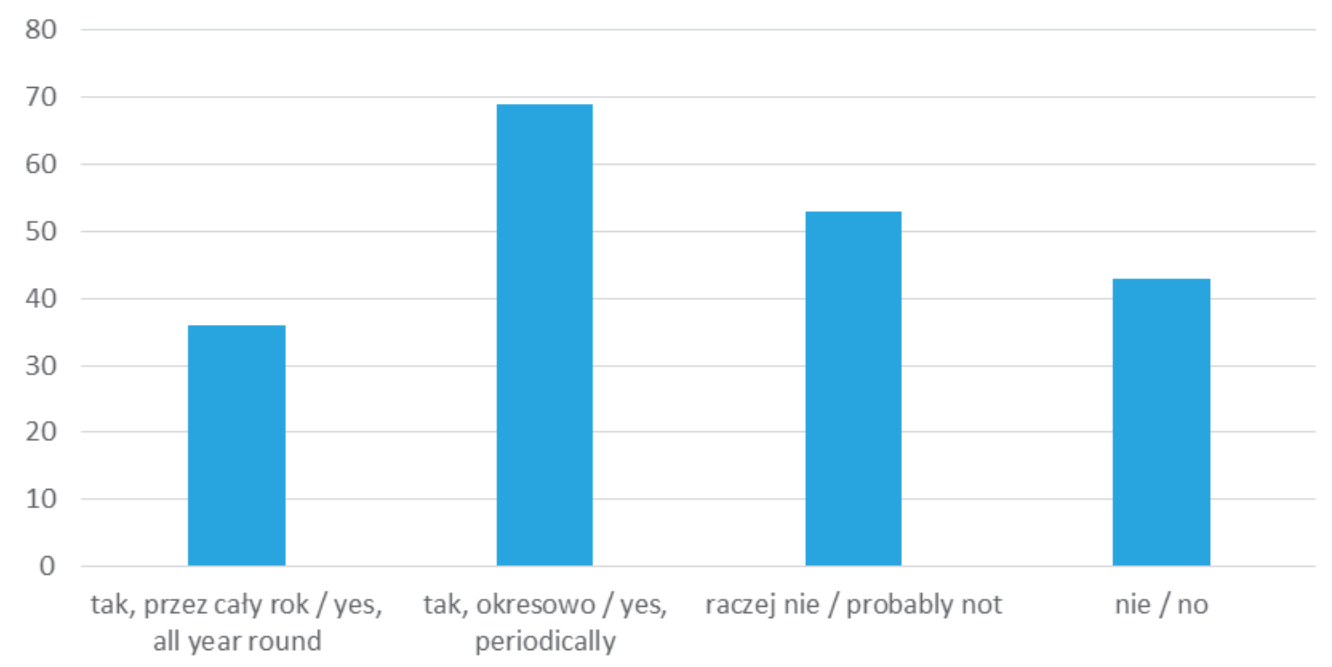

Rycina 3. Odpowiedzi badanych na pytanie „Czy uważasz, że potrzebujesz suplementacji witaminy D3?” Figure 3. Respondents' answers to the question, "Do you think you need vitamin D3 supplementation?"

Źródło: opracowanie własne.

Source: author's own analysis.

\section{Dyskusja}

Według The Third National Health and Nutrition Examination Survey niedobór witaminy D dotyczy od 25\% do 57\% dorosłych w Stanach Zjednoczonych. Polscy badacze przedstawili wyniki wskazujące na głęboki deficyt lub niedostateczne zaopatrzenie ustroju w witaminę D (stęż. 25(OH)D poniżej $30 \mathrm{ng} / \mathrm{ml}$ ) w okresie zimy u 90,3\% osób [12]. To pokazuje, jak wielka jest potrzeba suplementacji witaminy D i wyrównywania niedoboru kalcytriolu. Według B. Kaźmierskiej [13] należy rekomendować jedynie leki lub preparaty posiadające standaryzację i zwrócić szczególną uwagę na lepszą przyswajalność w formie kapsułki olejowej, co wynika z rozpuszczalności witaminy D w tłuszczach. Suplementowanie witaminy $D$ w innej postaci powinno towarzyszyć posiłkowi bogatotłuszczowemu.

Z przeprowadzonych badań własnych wynika, że należy dążyć do stałego, systematycznego uświadamiania młodzieży szkół średnich na temat suplementacji witaminy D. Przekazywanie fachowej wiedzy wiązałoby się ze wzrostem świadomości na temat profilaktyki wielu chorób i odpowiedzialności młodych dorosłych za swoje zdrowie. Edukacja dzieci i młodzieży w zakresie przeciwdziałania chorobom cywilizacyjnym razem z wdrażaniem kompetencji społecznych jest zawarta w podstawach programowych szkół podstawowych i ponadpodstawowych m.in. wychowania fizycznego
[14]. Temat edukacji jest równie trudny, co ważny biorąc pod uwagę wzrost liczby reklam z 4,6\% do 24,7\%, czyli o 20 p.p. w latach 1997 do 2015 z sektora obejmującego produkty zdrowotne [3]. O skuteczności tych reklam świadczy fakt, że prawie 70\% Polaków deklaruje, że nabywa leki dostępne bez recepty lub suplementy diety [15].

Do tej pory rzadko realizowane były badania dotyczące oceny świadomości polskiej młodzieży na temat żywienia oraz jej zmian pod wpływem edukacji szkolnej. Według badaczy z Uniwersytetu Rolniczego w Krakowie brak świadomości negatywnych następstw nieprawidłowego żywienia jest częściowo wynikiem zbyt małej uwagi poświęcanej tej problematyce w programie nauczania [16]. Z kolei, badania przeprowadzone przez TNS Polska w 2014 r. wykazały, że jedynie 27\% pytanych trafnie określiło suplement diety, a $41 \%$ mylnie przypisało im właściwości lecznicze oraz połowa ankietowanych sądziła, że suplementy są tak samo kontrolowane jak leki [17]. Może to wskazywać na niedostateczny brak edukacji nie tylko młodzieży szkolnej, ale również całego społeczeństwa.

Opracowanie zebranych przez nas danych umożliwiło zapoznanie się ze stanem wiedzy młodzieży szkół średnich dotyczącej różnic między suplementami diety a lekami oraz pozwoliło zbadać poziom wiedzy na temat konieczności suplementowania witaminy D. W związku 
z brakiem podobnych badań istniała potrzeba opracowania przedstawionego tematu w formie publikacji. Należy jednak uwzględnić ograniczone możliwości jednoznacznego wnioskowania na podstawie pojedynczego badania, które mimo swoich ograniczeń wskazuje potrzebę dalszego zgłębiania poruszonego tematu i przeprowadzenia znacznie poszerzonych badań na terenie Polski.

\section{Wnioski}

Uzyskane informacje umożliwiły określenie stanu wiedzy młodzieży na powyżej przedstawione zagadnienie oraz ustalenie stopnia rozpowszechnienia suplementacji witaminy D3, a także pozwoliły na przedstawienie poniższych wniosków:

1. Istnieje potrzeba przeprowadzenia edukacji zdrowotnej wśród młodzieży szkół średnich województwa podkarpackiego w zakresie suplementacji witaminy $\mathrm{D}$ oraz różnic między lekiem a suplementem diety.

2. Istnieje konieczność przeprowadzenia szerszych badań wśród młodzieży na temat suplementacji witaminy D z uwzględnieniem bardziej szczegółowych narzędzi badawczych i analiz statystycznych.

\section{Piśmiennictwo}

1. Ustawa z dnia 25 sierpnia 2006 r. o bezpieczeństwie żywności i żywienia.

2. Ustawa z dnia 6 września 2001 r. Prawo farmaceutyczne.

3. Prędka E. Emisja przekazów handlowych produktów zdrowotnych i leków w programach telewizyjnych, 2015.

4. https://powiadomienia.gis.gov.pl/ [dostęp z dnia 31.03.2020].

5. Zdrojewicz Z, Chruszczewska E, Miner M. Wpływ witaminy D na organizm człowieka. Med Rodz. 2015; 2(18): 61-66.

6. Żukowska-Szczechowska E, Kiszka B. Niedobór witaminy D - rozpoznawanie i postępowanie w celu redukcji ryzyka sercowo-naczyniowego u chorych na cukrzycę. Forum Zaburzeń Metabolicznych. 2011; 2(2): 151-157.

7. Gombart AF, Borregaard N, Koeffler HP. Human cathelicidin antimicrobial peptide (CAMP) gene is a direct target of the vitamin $\mathrm{D}$ receptor and is strongly up-regulated in myeloid cells by 1,25-dihydroxyvitamin D3. FASEB J 2005.
8. Wilk K, Drosdzol-Cop A. Rola witaminy D w położnictwie i ginekologii. Forum Położnictwa i Ginekologii 2018/2019.

9. Jorde R, Sneve M, Figenschau Y, Waterloo K. Effects of vitamin D supplementation on symptoms of depression in overweight and obese subjects: randomized double-blind trial. J Intern Med. 2008; 264(6): 599-609.

10. Zhang Y, Fang F, Tang J, et al. Association between vitamin D supplementation and mortality: systematic review and meta-analysis. BMJ. 2019; 366: 14673.

11. Kmieć P, Sworczak K. Korzyści i zagrożenia wynikające z suplementacji witaminą D. Forum Medycyny Rodzinnej 2017.

12. Płudowski P, Konstantynowicz J, Jaworski M, Abramowicz P, Ducki C. Ocena stanu zaopatrzenia w witaminę D w populacji osób dorosłych w Polsce. Standardy Medyczne. Pediatria. 2014; 11: 609-617.

13. Kaźmierska B. Witamina D - rola i znaczenie dla organizmu. Praca poglądowa w ramach specjalizacji z farmacji aptecznej.

14. Wieczorek M, Kumala R, Bronikowski M, Groffik D. Vademecum Nauczyciela. Wdrażanie podstawy programowej w szkole ponadpodstawowej. Wychowanie fizyczne. Warszawa; 2019.

15. Kasperczyk M. Apteki najlepszym miejscem do kupowania leków bez recepty oraz suplementów diety. 2012, 1-7.

16. Cieślik E, Siembida A, Kuś A, Folcik A, Kopeć A. Wpływ edukacji na świadomość żywieniową młodzieży szkół ponadgimnazjalnych $w$ aspekcie profilaktyki chorób dietozależnych. PHiE. 2014; 95(4): 927-933.

17. Raport „Świadome samoleczenie w Polsce - http://www. lekiczysuplementy.pl 2014" z badania przeprowadzonego na zlecenie platformy edukacyjno-informacyjnej http:// www.lekiczysuplementy.pl. [dostęp z dnia 31.03.2020].

Artykuł przyjęty do redakcji: 10.06.2020.

Artykuł przyjęty do publikacji: 18.09.2020.

Źródło finansowania: Praca nie jest finansowana z żadnego źródła. Konflikt interesów: Autorzy deklarują brak konfliktu interesów.

\author{
Adres do korespondencji: \\ Katarzyna Kozubal \\ ul. Leszczyńska 69D/54 \\ 25-326 Kielce \\ mail: kozubal.katarzyna@gmail.com \\ Collegium Medicum, Uniwersytet Jana Kochanowskiego w Kielcach
}

